\title{
PERLINDUNGAN HUKUM TERHADAP PENCIPTA ATAU PEMEGANG HAK CIPTA LAGU DALAM PEMBAYARAN ROYALTI
}

\author{
Ampuan Situmeang*, Rita Kusmayanti*** \\ Fakultas Hukum, Universitas Internasional Batam
}

\begin{abstract}
Intellectual property is the result of a work for an author that has exclusive rights that only exists and attribute to the owner or the rights holder of the work. Other parties wishing to use the copyright is required to obtain the permission from the copyright holder or creator. The research questions how the legal protection regarding royalties is given for the creator or copyright holder of the song and how to file objections if the use of a song without royalty payment. The research used a normative research method. Data was analyzed by using a qualitative-descriptive approach. It can be concluded the use of exclusive rights is still not properly implemented. The formation of LMKN is a form of protection given by the government to the copyright of songs given also provides tariffs on royalties that must be agreed by users. Dispute resolution can be done through litigation and nonlitigation. Dispute resolution involving different countries can be done through the WIPO Arbitration and Meditation Center.
\end{abstract}

Keywords: Legal Protection, Copyright, Song, Royalty.

\begin{abstract}
Abstrak
Kekayaan intelektual adalah hasil karya seorang penulis yang memiliki hak eksklusif yang hanya ada dan melekat pada pemilik atau pemegang hak atas suatu karya. Pihak lain yang ingin menggunakan hak cipta tersebut harus memperoleh izin dari pencipta atau pemegang hak cipta. Penelitian mempertanyakan bagaimana perlindungan hukum bagi pencipta atau pemegang hak cipta lagu terhadap pembayaran royalti dan bagaimana menyelesaikan keberatan jika terdapat penggunaan lagu tanpa pembayaran royalti. Penelitian ini menggunakan metode penelitian normatif. Data dianalisis dengan menggunakan pendekatan kualitatif-deskriptif. Dapat disimpulkan bahwa penggunaan hak eksklusif masih belum dilaksanakan dengan baik. Pembentukan LMKN adalah bentuk perlindungan yang diberikan oleh pemerintah terhadap hak cipta lagu yang diberikan juga memberikan tarif royalti yang harus disepakati oleh pengguna. Penyelesaian sengketa dapat dilakukan melalui litigasi dan non-litigasi. Penyelesaian sengketa yang melibatkan berbagai negara dapat dilakukan melalui Pusat Meditasi dan Arbitrasi WIPO.
\end{abstract}

Kata Kunci: Perlindungan hukum, hak cipta, lagu, royalty.

\footnotetext{
*Alamat Korespondensi : ampuan.situmeang@uib.ac.id

** Alamat Korespondensi : radenayukusuma@gmail.com
} 


\section{A. Latar Belakang Masalah}

Keanekaragaman seni serta budaya di Indonesia merupakan sebuah kekayaan yang dimiliki berdasarkan banyaknya suku, bahasa, dan agama yang menyebar di penjuru Indonesia mulai dari sabang hingga merauke menjadikan pluralitas yang memiliki potensi nasional dan diperlukan perlindungan terhadap kekayaan atas beragam seni dan budaya tersebut. ${ }^{1}$ Setiap manusia memiliki daya pikir yang cakap sehingga dapat melahirkan ilmu pengetahuan, teknologi dan karya seni, di mana hasil karya seni yang berhasil diciptakan harus mendapatkan penghormatan dan penghargaan terhadap sebuah karya cipta yang merupakan perwujudan dari sebuah pengekspresian atas kreatif Pencipta. ${ }^{2}$ Hasil ciptaan yang berhasil dikembangkan merupakan karya cipta seorang atau sekelompok orang yang mempunyai kemampuan menghasilkan karya cipta yang harus mendapat perlindungan hukum atas apa yang telah ia ciptakan.

Kekayaan intelektual, yang selanjutnya disebut KI, adalah objek yang tidak memiliki bentuk yang berasal dari hasil aktivitas intelektual manusia yang diekspresikan dalam karya berhak cipta atau dalam bentuk karya yang berhasil ditemukan. ${ }^{3}$ Dalam proses membuat sebuah karya intelektual yang berasal dari berbagai ilmu seperti pada ilmu pengetahuan, seni, budaya dan juga tekonologi. Ilmu pengetahuan serta teknologi yang semakin meningkat menyokong peranan yang cukup besar terhadap beranekaragamnya KI.

Sejalan dengan diberlakukannya Undang-Undang Nomor 28 Tahun 2014 Tentang Hak Cipta menimbulkan permasalahan tersendiri bagi Pencipta atau Pemegang Hak Cipta terkhusus terhadap Pencipta karya lagu yang mana dalam peraturan tersebut telah memperoleh perlindungan secara preventif, karena dengan adanya undang-undang hak cipta yang ada belum dapat memberikan jaminan terhadap terlindunginya hak eksklusif Pencipta karya lagu, semakin dengan berkembangnya era globalisasi masih menyisahkan pelanggaran terhadap karya cipta yang didasarkan minimnya pengetahuan dan kesadaran terhadap hukum KI khususnya Hak Cipta serta kurangnya apresiasi masyarakat terhadap hak-hak atau kewenagan Pencipta atau Pemegang Hak Cipta yang mendapatkan perlindungan hukum. Pada Pasal 40 huruf d Undang-Undang Hak Cipta, yaitu terhadap karya lagu atau musik dengan atau tanpa teks merupakan ciptaan yang mendapatkan perlindungan. Hak ekonomi yang dipunyai Pencipta atau Pemegang Hak Cipta

\footnotetext{
${ }^{1}$ Bronto Asmoro, Buku Saku Super Pintar IPS “Ilmu Pengetahuan Sosial”, Jakarta: Grasindo, 2010, hlm 28.

${ }^{2}$ Emma Valentina Teresha Senwe, Efektifitas Pengaturan Hukum Hak Cipta Dalam Melindungi Karya Seni Tradisional Daerah, Jurnal LPPM Bidang Ekososbudkum Volume 2 Nomor 2 Tahun 2015 Edisi Oktober, 2015, hlm 12.

${ }^{3}$ Nurjannah, Kekayaan intelektual, diambil pada $17 \quad$ Mei 2019 dari http;//nurjannah.staff.gunadarma.ac.id/
} 
merupakan bentuk apresiasi yang diberikan oleh pemerintah dan mayarakat dengan dipergunakannya karya lagu tersebut dengan tujuan komersial. ${ }^{4}$

Permasalahan yang timbul dari pelanggaran tersebut adalah kurangnya kesadaran masyarakat tentang penerapan hak mengumumkan (performing rights) yang mengakibatkan terjadi kerugian secara materiil dan immaterial yang dialami Pencipta atau Pemegang Hak Cipta Karya Lagu, serta lemahnya penegakan hukum yang melekat pada Undang-Undang Nomor 28 Tahun 2014 Tentang Hak Cipta dimana pelanggarnya yang terjadi tidak mendapatkan penanganan yang tepat atas pembayaran royalti

\section{B. Rumusan Masalah}

Berlandaskan uraian terhadap latar belakang diatas, maka Penulis mencoba menganalisis mengenai :

1. Apakah perlindungan hukum bagi Pencipta atau Pemegang Hak Cipta karya lagu terhadap pembayaran royalti sudah sesuai dengan peraturan hukum?

2. Bagaimana cara menyelesaikan sengketa apabila terjadi penggunaan karya lagu tanpa membayar royalti ?

\section{Metode Penelitian}

Metode yang dipergunakan dalam penelitian untuk melakukan analisis suatu permasalahan hukum, dapat mempergunakan metode pendekatan normatif. ${ }^{5}$ Dalam orientasi penelitian ini dilakukan dengan mengamati realitas hukum dalam berbagai norma atau kaidah-kaidah hukum yang telah terbentuk. ${ }^{6}$ Serta melakukan wawancara sebagai data primer untuk mendukung data sekunder. Pendekatan yang digunakan adalah statua approach yang melakukan penelitian terhadap produk hukum. ${ }^{7}$

Bahan-bahan hukum yang dipergunakan dalam penulisan penelitian ini berupa: pertama bahan hukum primer, Bahan hukum primer, Undang-Undang Dasar Republik Indonesia Tahun 1945; Undang-Undang Nomor 28 Tahun 2014 Tentang Hak Cipta; Peraturan Menteri Hukum dan Hak Asasi Manusia Nomor 42 Tahun 2016 Tentang Pelayanan Permohonan Kekayaan Intelektual Secara Elektronik. Kedua Bahan hukum sekunder, berupa buku, artikel, jurnal, naskah pidato pengukuhan guru besar, naskah orientasi ilmiah, dan naskah akdemik.

Ketiga Bahan hukum tersier kamus besar bahasa indonesia umum, berita.

${ }^{4}$ Fiat Justisia, Volume 10 Issue 3, hlm 489 Habi Kusno, Perlindungan Hukum Hak Cipta Terhadap Pencipta Lagu yang Diunduh Melalui Internet, Fiat Justisia 2016.

${ }^{5}$ Syahruddin Nawi, Penelitian Hukum Normatif Versus Penelitian Hukum Empiris, Cet. 6, Makassar: PT Umitoha Ukhuwah Geafika, 2018, hlm 7.

${ }^{6}$ Syahruddin Nawi, Penelitian Hukum Normatif Versus Penelitian Hukum Empiris, Cet. 6, Makassar: PT Umitoha Ukhuwah Geafika, 2018, hlm 7. ${ }^{7}$ Ibid 
Penulis melakukan pengumpulan data yang didapatkan dari hasil penelitian yang dilanjutkan dengan menganalisis menggunakan metode deskriptif-kualitatif, maksudnya adalah dari hasil data-data yang berhasil Penulis kumpulkan kemudian digunakan dalam menentukan isi atau makna dari aturan hukum yang menjadi landasan penyelesaian permasalahan hukum atas obyek yang dikaji. Terhadap data yang berhasil dikumpulkan memakai bahan-bahan yang berasal dari penelitian, baik yang berasal dari data primer ataupun data sekunder dilakukan analisa menggunakan metode kualitatif yang berdasarkan dengan landasan teori serta peraturan perundang-undangan yang memiliki keterkaitan dengan penulisan dan penelitian ini, yang kemudian Penulis sajikan secara deskriptif.

\section{Hasil Penelitian dan Pembahasan}

\section{Hasil Penelitian}

\section{1) Hasil Wawancara}

Dalam pertanyaan yang saya berikan kepada Pencipta lagu serta penyanyi yaitu Erdian Aji Prihartanto yang dikenal dengan nama Anji melalui direct massage pada tanggan 21 Maret 2019 yang kemudian dibalas pada tanggal 30 November 2019 bahwasanya dalam penarikan royalti Pencipta harus mendaftarkan dirinya kepada LMK terlebih dahulu, sehingga Pencipta tersebut menjadi anggota LMK dan mendaftarkan lagunya kepada LMK yang nantinya dalam proses pendistribusian dilakukan oleh LMK berdasarkan kuasa yang diberikan oleh Pencipta tersebut. Hasil Penelitian Pustaka dan Studi Dokumen

\section{2) Hasil Penelitian dan Studi Dokumen}

\section{a. Kasus Pengguna (user) Lagu yang Tidak Membayar Royalti}

Berdasarkan putusan pengadilan nomor 670/Pid.sus/2015/PN Sgl Pemilik Monalisa Pub dan Karaoke yaitu Suhanto Als Alim Bin Sunanto yang tempat usahanya beralamat di Jl. Komplek Perkantoran Gubernur Propinsi Kep. Bangka Belitung. Monalisa Pub dan Karaoke karena tidak dapat memperlihatkan izin atau lisensi resmi terhadap musik atau lagu-lagu yang ada di Monalisa Pub dan Karaoke karena segala perizinan dari LMK. Sehingga dijatuhkan pidana penjara selama 1 (satu) bulan dan denda sejumlah Rp2.000.000,00 (dua juta rupiah) dengan masa penahanan yang telah dijalani Terdakwa dikurangkan seluruhnya dari pidana yang dijatuhkan, maka Terdakwa tetap ditahan. Membebankan kepada Terdakwa membayar biaya perkara sejumlah Rp10.000,00 (sepuluh ribu rupiah).

Berdasarkan putusan pengadilan nomor 10/Pid.B.2014/PN Njk. Pada bulan Maret tahun 2008 Nur Salam menciptakan sebuah lagu dengan judul Oplosan dan telah diumumkan untuk pertama kali dengan cara menyiarkan melalui VCD (cakram optik) yang dinyayikan oleh Trio Gomik Feat Nur Bayan dengan aransemen jaipong pada bulan Juni tahun 2008. Pada acara Semarak Tahun Baru 1 Januari tahun 2013 di Daerah Sumber Boto Kabupaten Jombang, Eni Sagita yang beralamat di Dusun Tanjung Desa Pace kulon Kabupaten Nganjuk di iringi oleh Om Sagita tanpa seizin Pencipta lagu telah menyanyikan lagu dengan judul Oplosan dan nyanyian tersebut kemudian di dokumentasikan menggunakan cara direkam oleh D'va Shoting dan kemudian memori master diserahkan kepada Eni Sagita yang diperjual belikan menggunakan VCD di pasaran pada daeraj Jawa Timur. Pengadilan menjatuhkan pidana penjara selama 4 (empat) bulan dan denda sebesar Rp. 1.000.000,- (satu juta rupiah). 
Pada 19 Juli $2017^{8}$, panel arbitrase dari Pusat Arbitrase dan Mediasi WIPO memutuskan masalah dalam sengketa antara penerbit musik besar dan independen BMG, Pemusik, Penerbitan Musik Sony / ATV / EMI, Penerbitan Universal Music dan Warner serta AEDEM, dan Lembaga hak kolektif Spanyol SGAE. Arbitrase yang menanganti kasus tersebut memfokuskan terhadap 2 (dua) klaim yaitu: 1) Penerimaan royalti yang tidak adil yang diterima dari Pengguna (user) lagu oleh SGAE dan pendistribusian royalti oleh SGAE kepada Pencipta atau Pemegang Hak Cipta lagu dan; 2)Pendistribusian royalti yang tidak tepat untuk penggunaan musik yang tidak terdengar atau hampir tidak terdengar

\section{b. Pembayaran Royalti oleh Pengguna (user)}

Fakultas Ekonomi, Universitas Indonesia, mengadakan acara tahunan yaitu Festival Jazz Goes To Campus (JGTC) yang ke-39. ${ }^{9}$ Pada tahun ini penyelenggara ingin menghadirkan momen yang belum pernah terjadi sebelumnya, yang menawarkan kolaborasi lintas generasi dan menunjukkan penghargaan kepada komposer atau Pencipta lagu dengan melakukan kerja sama dengan Lembaga Manajemen Kolektif yaitu Wahana Musik Indonesia (WAMI). Komite JGTC 2016 akan membayar royalti kepada komposer atau penulis lagu melalui WAMI yang mengambil 2\% (dua persen) dari harga tiket, sehingga dalam alur pembayaran komposer atau Pencipta lagu dilaksanakan dalam 2 (dua) tahapan yaitu pembayaran sebelum dan sesudah acara berlangsung.

Dalam upaya pembayaran royalti dengan besaran royalti yang telah dikeluarkan oleh Lembaga Manajemen Kolektif Nasional (LMKN) terjadi polemik yang dialami para pengusaha karaoke yang tergabung dalam Asosiasi Pengusaha Hiburan Jakarta (ASPHIJA) ${ }^{\mathbf{1 0}}$, hal ini dilatar belakangi oleh besaran tarif royalti yang dikenakan pada karaoke eksekutif berbeda dengan tarif royalti pada karaoke keluarga.

\section{c. Penerimaan Royalti oleh Pencipta Lagu}

Pendistribusian yang dilakukan mulai tanggal 6 Agustus 2018 merupakan hasil dari pembayaran royalti yang dibayarkan oleh pengguna (user) lagu dalam periode Januari hingga Desember 2017 dengan perolehan royalti yang berasal dari kombinasi dari Lembaga Manajemen Kolektif Nasional (LMKN) dan yang dikumpulkan secara langsung oleh KCI berjumlah Rp. 4.660.776.000,- (empat miliar enam ratus enam puluh juta tujuh ratus tujuh puluh enam ribu rupiah).

Tahun 2017 tepatnya bulan April Wahana Musik Indonesia (WAMI) ${ }^{11}$ telah mendistribusikan royalti atas hak menggumumkan (performing right) kepada Pencipta dan Pemilik Hak Cipta. Royalti yang di distribusikan merupakan royalti yang didapatkan atas layanan digital tepatnya pada layanan iTunes yang didapat selama periode 2013-2015 dan Sonylive. Proses pendistribusian royalti atas kedua

\footnotetext{
${ }^{8}$ Crefovi, Alternative Dispute Resolution in the entertainment and creative industries. Dilihat pada 23 Januari 2020 dari https://crefovi.com/articles/alternative-dispute-resolution-entertainment-creativeindustries/

${ }^{9}$ Beritaagar.id dilihat pada 12 November 2019 dari https://beritagar.id/artikel/seni-hiburan/jgtc-2016festival-musik-pertama-yang-membayar-royalti-komposer

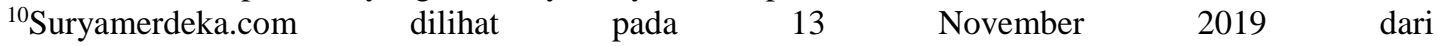
https://www.suaramerdeka.com/entertainment/baca/287/pengusaha-karaoke-eksekutif-jakarta-bayarroyalti-via-lmkn

${ }^{11}$ Wahana Musik Indonesia, Digital Royalty Distributor, 18 May 2017. Diambil pada 13 Desember 2019 dari https://www.wami.id/en/2017/05/18/distribusi-royalti-digital/
} 
layanan tersebut berdasarkan laporan penggunaan atas karya musik yang diberikan oleh Apple Inc. dan Sony Music Indonesia kepada WAMI. Jumlah royalti yang di distribusikan kepada para Pencipta dan Pemilik Hak Cipta yang memberikan kuasa kepada WAMI berjumlah sekitar Rp. 1.200.000.000,- (satu milyar dua ratus juta rupiah).

\section{Pembahasan Penelitian}

\section{Perlindungan Hukum Bagi Pencipta atau Pemegang Hak Cipta Karya Lagu Terhadap Pembayaran Royalti}

Perlindungan berasal dari kata dasar lindung yang memiliki artian sebagai tempat berlindung atau hal-hal akibat suatu perbuatan dan sebagainya yang memperlindungi. Melindungi adalah salah satu dari sekian kata yang tercipta dari kata dasar lindung yang memiliki arti suatu tindakan atau suatu cara untuk memberikan sebuah perlindungan yang mana dalam perlindungan juga memberikan ruang sebagai tempat berlindung sebagai bentuk dari memberikan sebuah bantuan.

Memberikan sebuah perlindungan bagi masyarakat merupakan cita-cita bangsa Indonesia yang mana telah dicanangkan sejak berdirinya Negara Republik Indonesia hal ini terbukti dengan dimasukannya dalam Pembukaan Undang-Undang Dasar Negara Republik Indonesia Tahun 1945 pada alenia ke-4 (empat) yang berbunyi “... untuk membentuk suatu Pemerintahan Negara Indonesia yang melindungi segenap bangsa Indonesia dan seluruh tumpah darah Indonesia dan untuk memajukan kesejahteraan umum, mencerdaskan kehidupan bangsa dan ikut melaksanakan ketertiban dunia yang berdasar kemerdekaan, perdamaian abadi dan keadilan sosial..."

Pasal 28 huruf G pada UUD tahun 1945 menekankan bahwa setiap orang memiliki hak sehubungan dengan perlindungan atas diri pribadi, keluarga, masyarakat atas kehormatan dan martabat serta harta benda yang berada dalam kuasanya. Dengan artian subyek hukum dari negara Indonesia memiliki hak untuk mendapatkan keamanan, perlindungan dari ancaman yang menyebabkan ketakutan karena semua hal tersebut merupakan hak asasi manusia.

Sehubungan dengan peraturan yang tertulis mengenai perlindungan hukum yang diberikan kepada setiap orang, hal yang serupa juga di ungkapkan oleh Philipus M. Hadjon yang memberikan pendapat bahwasanya perlindungan berdasarkan harkat dan martabat akan pengukuhan hak asasi manusia yang di miliki oleh subyek hukum yang mana subyek hukum tersebut adalah masyarkat Indonesia yang berlandakan atas suatu peraturan ataupun kaidah-kaidah yang dapat dijadikan landasan sebuah perlindungan dari suatu hal lainnya.

Berdasarkan pengertian atas perlindungan diatas dapat ditarik sebuah bundel, bahwasanya pada dasarnya perlindungan adalah sebuah bentuk atau tindakan yang memberikan suatu upaya dalam melindungi setiap orang dari suatu tindakan atau perbuatan yang merugikan subjek tersebut berdasarkan hak asasi manusia. Perlindungan hukum merupakan sebuah wadah untuk memberikan tempat berlindung bagi setiap masyarakat yang berlandaskan hukum atau kaidah-kaidah yang berlaku.

Berlandaskan Undang-Undang Dasar Tahun 1945 dalam upaya memberikan perlindungan dalam bidang kekyaan intelektual dan juga dengan masuknya Indonesia sebagai salah satu anggota pada Organisasi Perdagangan Dunia atau yang 
lebih dikenal dengan World Trade Organization yang mana dalam organisasi ini telah di sepakatinya perjanjian internasional mengenai perjanjian TRIPs.

Dalam penerapan peraturan perundang-undangan sebagai negara anggota diharuskan menerapkan perinsip-prinsip dasar yang dianut dalam konvensi-konvensi yang telah diadakan. Salah satunya konvensi Bern yang mana Indonesia adalah peserta pada konvensi ini sehingga terdapat kewajiban memasukan unsur dasar dalam undang-undang yang diberlakukan di Indonesia. Perinsip dasar yang harus dimasukan kedalam peraturan perundang-undangan tersebut memiliki 3 (tiga) bagian yaitu yang pertama adalah prinsip national treatment yang mana ciptaan yang lahir atau tercipta dari salah satu negara anggota ataupun peserta dari perjanjian ini atas ciptaan yang pertama kali diterbitkan pada salah satu negara anggota haruslah mendapatkan perlindungan hukum yang sama seperti pada pencipta yang merupakan warga negaranya sendiri, sehingga tidak ada pembedaan asal usul kenegaraan karena negara anggota atau negara peserta yang turut serta dalam konvensi ini dianggap sebagai satu kesatuan dalam penerbitan ciptaan.

Prinsip kedua adalah prinsip automatic protection yang mana dalam memberikan perlindungan hukum dilakukan secara langsung tanpa harus melaksanakan suatu persyaratan apapun, karena sebagai sesama negara peserta harus memberikan perlindungan hukum secara penuh tanpa adanya persyaratan yang harus di lakukan dalam mendapatkan suatu perlindungan. Karena pada dasarnya perlindungan hukum adalah hak asasi manusia.

Prinsip yang ketiga adalah prinsip independence of protection merupakan sebuah bentuk perlindungan hukum yang di berikan kepada Pencipta karya tidak melihat asal usul dari negara Pencipta, hal ini dikarenakan para negara peserta atau negara anggota diharuskan untuk melakukan peratifikasian prinsip-prinsip pada konvensi Bern yang telah dihadiri dan prinsip tersebut mendapat kesamaan kedudukan disetiap negara anggota atau negara peserta.

Sebagai anggota dari organisasi internasional mengharuskan Indonesia untuk meratifikasi peraturan mengenai KI dalam bidang Hak Cipta sehingga terbentuklah Undang-Undang Hak Cipta yang mana merupakan peraturan terbaru yang mengatur tentang Hak Cipta. Pada kenyataannya walaupun pembentukan undang-undang berdasarkan konsep dasar konvensi bern yang mengatakan bahwa perlindungan hukum atas hak cipta diberikan dengan otomatis ketika ciptaan telah berwujud atau telah selesai dibuat pada nyatanya dalam masyarkat masih banyak melakukan pelanggran terhadap hak cipta kususnya pada karya lagu, hal ini yang menjadikan ketidak adanya sebuah perlindungan hukum padahal sudah jelas dinyatakan pada Pasal 1 angka 1. Namun tidak berjalannya aturan yang telah diterbitkan menyebabkan keresahan para Pencipta atau Pemegang Hak Cipta karena pelanggaran yang dilakukan telah merenggut hak ekonomi yang seharusnya dinikmati pencipta, dengan kata lain bahwa das sollen dan das sein tidak seberjalan dengan semestinya.

Lagu merupakan sebuah hasil ciptaan yang berasal dari sebuah gagasan yang dimiliki oleh Pencipta yang kemudian dikembangkan yang berasal berdasarkan berapa unsur. Unsur utama dalam penciptaan sebuah lagu adalah Pencipta menuliskan gagasan yang dimiliki sehingga terbentuk sebuah syair atau lirik lagu yang kemudian di padu-padankan dengan penggunaan alat musik yang Pencipta kuasai sehingga membentuk sebuah nada atau melodi yang disesuaikan dengan syair atau lirik lagu tersebut. Sehingga dari rangkaian proses yang Pencipta bentuk 
menghasilkan sebuah lagu dengan alunan melodi yang harmonis dan dapat dirasakan melalui indra pendengaran manusia.

Keberhasilan Pencipta dalam menghasilkan lagu dalam bentuk nyata dari gagasan yang dimiliki sehingga lagu tersebut merupakan hasil dari ciptaan. Sehingga Pencipta secara langsung mendapatkan hak cipta atas terwujudnya lagu tersebut, dan memiliki hak-hak yang di lindungi oleh pemerintah yang telah diatur dalam Pasal 4.

Upaya pemerintah dalam memberikan sebuah perlindungan terhadap Pencipta telah diatur dalam Undang-Undang Hak Cipta telah tertuang jelas dengan adanya pasal-pasal yang ada didalamnya. Pada Pasal 4 telah dibahas mengenai pemerintah yang telah memberikan perlindungan kepada pencipta menyangkut hak eksklusif yang merupakan hak pada setiap Pencipta ataupun Pemegang Hak Cipta. Namun terjadi pembedaan antara hak yang dimiliki oleh Pencipta atau Pemegang Hak Cipta, perbedaan yang dimaksud diantaranya adalah pada Pencipta melekat sebuah hak yang akan terus ada pada karya ciptaannya mesikupn ciptaan telah dialihkan atau dipindah tangankan kepada orang lain, hak tersebut dikenal dengan sebutan Hak Moral, peraturan ini telah tercantum dengan jelas pada Pasal 5.

Hak lain yang diperoleh oleh Pencipta adalah Hak ekonomi yang dimiliki oleh pencipta merupakan sebuah hasil cari pencapaian karyanya, yang mana dalam melakukan hak ekonomi yang dimiliki tersebut dapat memakmurkan atau mensejahterakan pencipta selaku pemilik hak cipta dari lagu yang diciptakan tersebut, hal inilah yang merupakan sebuah apresiasi bagi pencipta dalam menciptakan sebuah karya cipta. Karena pada dasarnya pembentukan karya merupakan suatu hal yang sulit karena menguras fikiran serta tenaga dalam proses pembuatannya. Mengenai hak eksklusif dalam pemanfaatan hak ekonomi sesuai dengan Pasal 9.

Pelaksanaan hak ekonomi yang telah disebut diatas, Pencipta atau Pemegang Hak cipta juga mempunyai kewenangan dalam memberikan perizinan seperti yang telah tertera dalam Pasal 9 Ayat 3, pemberian izin yang berupa lisensi terhadap orang lain dalam mempergunakan ciptaannya dan Pencipta atau Pemegang Hak Cipta berhak menerima imbalan berupa pembayaran royalti dari perbuatan penggunaan karya lagu tersebut. Sedangkan pada Pemegang Hak Cipta sesuai dengan Pasal 5 Ayat 2, tidak memiliki Hak Moral karena hak yang dimilikinya hanya berupa Hak Ekonomi atas ciptaan yang telah diterimanya. Namun Hak Ekonomi yang dimiliki Pemegang Hak Cipta sama halnya dengan Hak Ekonomi yang dimiliki oleh Pencipta, sehingga yang jadi pembedanya antara Pencipta dengan Pemegang Hak Cipta hanya terletak pada Hak Moral.

Pencipta atau Pemegang Hak Cipta memiliki Hak Ekonomi atas Ciptaan. Hak Ekonomi yang umum dipergunakan adalah pendistribusian dan mengumumkan. Hak Menggumumkan adalah sebuah hak yang dipunyai oleh Pencipta atau Pemegang Hak Cipta dalam melaksanakan sebuah pertunjukan atas ciptaan atau penyiaran ciptaan lagu dengan tujuan komersial. Sehingga dengan demikian bilamana orang lain yang ingin mempergunakan hak ekonomi atas ciptaan maka harus terlebih dahulu mendapatkan izin dari Pencipta atau Pemegang Hak Cipta yang pemberian izin tersebut diberikan secara tertulis atau lebih dikenal dengan lisensi penyiaran. Apabila seseorang yang tidak memiliki lisensi dari Pencipta atau Pemegang Hak Cipta maka dilarang melakukan penggunaan dan pengumuman atas ciptaan secara komersial. Pengaturan terhadap keharusan bagi Pengguna (user) dalam melakukan lisensi telah diatur dalam Undang-Undang Hak Cipta pada bab xi. 
Penggunaan ciptaan yang dipergunakan Pengguna (user) biasanya dituangkan dalam sebuah perjanjian tertulis yang didasarkan pada kesepakatan Pencipta dengan Pengguna (user) yang dikenal dengan lisensi, dalam lisensi tersebut juga dituangkan besaran penerimaan atas penggunaan ciptaan Pencipta atau Pemegang Hak Cipta yang lebih dikenal dengan royalti. Karena pada hakikatnya royalti adalah hak yang memang harus diterima oleh Pencipta atau Pemegang Hak Cipta atas imbalan dari pemanfaatan hak ekonomi dari sebuah ciptaan. Dengan kata lain bahwa royalti merupakan hak mutlak yang dimiliki oleh Pencipta atau Pemegang Hak Cipta yang diterima dalam bentuk imbalan uang.

Pada dasarnya dalam mendapatkan perlindungan atas suatu Ciptaan, Pencipta tidak perlu mendaftarkan ciptaan tersebut karena pada hakikatnya perlindungan atas hak cipta terhadap ciptaan tersebut timbul secara otomatis yang mana telah diatur dalam Pasal 1. Namun yang terjadi dalam masyarakat masih banyak yang tidak memahami sepenuhnya bahwasanya ciptaan merupakan sebuah Hak Cipta yang harus dihargai, terutama dalam bidang ciptaan lagu. Bahwa untuk mendapatkan perlindungan hak cipta Pencipta harus mendaftarkan dirinya kepada Lembaga Manajemen Kolektif ataupun Pencipta dapat mencatatkan ciptaannya kepada Direktorat Jendral Kekayaan Intelekual. Tujuan dari pendaftaran ini merupakan langkah awal sebagai bukti yang kuat serta memiliki kekuatan hukum apabila ada Pengguna (user) yang mempergunakan ciptaan lagu dengan tujuan komersial maka Pencipta dapat menggugat Pengguna (user) atas kerugian yang dialaminya.

Bentuk keseriusan pemberian perlindungan dibuktikan oleh pemerintah terhadap KI khususnya pada bidang Hak Cipta dibentuklah sebuah lembaga yang bertujuan untuk memberikan perlindungan terhadap Hak Ekonomi yang dipunyai Pencipta berdasarkan kuasa yang diberikan atas Ciptaan yang disebut sebagai LMKN yang mana merupakan perwujudan dari Pasal 87 Undang-Undang Hak Cipta. Hak ekonomi yang dikelolah oleh LMKN ini yaitu berupa pengumpulan hasil dari royalti serta pengaturan tarif royalti yang digunakan oleh Pengguna (user). LMKN berada pada naungan Direktorat Jendral Kekayaan Intelektual yang memiliki beran cukup penting untuk mengawasi, membuat dan memberikan rekomendasi terhadap LMK yang berada dalam koordinasiannya.

LMKN cukup berperan aktif dalam pemberlakuan tarif yang dikenakan kepada Pengguna (user) dan metode pendistribusian royalti kepada Pencipta atau Pemegang Hak Cipta. Hal ini dikarenakan pada peraturan perundang-undangan sebelumnya tidak ada lembaga manajemen yang berasal dari pemerintah sehingga penarikan atas tarif royalti tidak mendapat ketentuan yang pasti. Pada dasarnya LMK terbagi atas dua yaitu LMKN pada bidang Hak Cipta dan LMKN dalam bidang Hak Terkait. Namun disini penulis akan membahas LMK pada bidang Hak Cipta.

Jauh sebelum dibentuknya LMKN oleh Pemerintah, telah berdiri sebuah LMK yang berbentuk badan hukum yaitu Karya Cipta Indonesia atau yang lebih terkenal dengan KCI. KCI berdiri pada tahun 1990 yang merupakan bentuk kepedulian dari para seniman pada jaman itu atas Pencipta atau Pemegang Hak Cipta khususnya dalam ciptaan lagu yang tidak mendapatkan hak menggandakan sebagaimana mestinya walaupun ciptaan dipergunakan oleh para Pengguna (user) dengan tujuan komersial. Hal inilah yang mendorong para musisi untuk mendirikan KCI sebagai wadah dari Pencipta atau Pemegang Hak Cipta untuk melindungi hak-hak atas ciptaannya. 
Pada tahun 2018 Karya Cipta Indonesia saat pendistribusian pada hari pertama sebanyak 125 (seratus dua puluh lima) Pencipta atau Pemegang Hak Cipta yang telah menerima pendistribusian atas pembayaran royalti yang telah dikuasakan kepada Lembaga Manajemen Kolektif tersebut. Total dari royalti yang di distribusikan sejumlah Rp. 4.660.776.000,- (empat miliar enam ratus enam puluh juta tujuh ratus tujuh puluh enam ribu rupiah) yang didapatkan dari pendistribusian atas Ciptaan berbagai genre lagu, yang telah dibayarkan oleh Pengguna (user) pada priode Januari hingga Desember 2017.

Pendistribusin royalti yang dilakukan oleh LMK merupakan sebuah bukti nyata bahwa menjadi anggota LMK penggunaan karya lagu pencipta atau pemegang hak cipta mendapatkan perlindungan atas karyanya serta merupakan bukti nyata bahwa penerapan Pasal 9 yang berkenaan dengan pendistribusian serta Pasal 8 merupakan keberhasilan atas peraturan yang telah ada. Sehingga memang perlu adanya penerapan yang tepat atas peraturan yang dikeluarkan oleh pemerintah guna melindungi Pencipta atau Pemegang Hak Cipta. Dari hasil penerimaan royalti tersebut dapat dipergunakan oleh Pencipta atau Pemegang Hak Cipta untuk mensejahterahkan kehidupan serta keluarganya menjadi lebih baik sesuai dengan UUD tahun 1945.

Pencipta atau Pemegang Hak Cipta dalam menyerahkan kuasa atas ciptaannya juga dapat memilih LMK lainnya, karena dewasa ini di Indonesia telah mempunyai beberapa LMK yang sudah mendapatkan Surat Keputusan dari Kementrian Hukum dan Hak Asasi Manusia antara lain yaitu Karya Cipta Indonesia, Wahana Musik Indonesia dan Royalti Anugrah Indonesia. Wahana Musik Indonesia merupakan sebuah Lembaga Manajemen Kolektif yang juga mengelola ciptaan dalam bidang lagu yang berfokus pada royalti atas Hak Menggumumkan.

Pada umumnya Wahana Musik Indonesia memiliki fungsi yang sama seperti Lembaga Manajemen Kolektif lainnya yaitu mendistribusikan ciptaan serta menarik royalti atas ciptaan tersebut yang kemudian royalti tersebut di bagikan kepada Pencipta atau Pemegang Hak Cipta. Wahana Musik Indonesia cukup aktif dalam memperluas ruang lingkupnya hal ini dibuktikan dengan dilakukannya perjanjian dengan lembaga (society) Internasional yang mana saat ini telah melakukan perjanjian dengan negara-negara yang ada di Asia, Amerika, Inggris dan 20 negara lainnya.

Dalam era industri 4.0 perkembangan teknologi kian bertambah pesat sehingga segala sesuatu yang dibutuhkan dapat dicari dengan mudah menggunakan teknologi, perkembangan teknologi juga tidak luput dari platform penyedia layanan musik yang mana saat ini banyak sekali layanan musik yang menyediakan lagu untuk di download atau hanya untuk sekedar dinikmati saja. Penggunaan lagu dalam platform tersebut merupakan sebuah kegiatan komersial yang menghasilkan uang bagi pemilik atau pendiri platform layanan lagu tersebut, sebut saja seperti iTunes merupakan platform lagu yang dimiliki berbagai macam lagu, termasuk lagu-lagu yang berasal dari Indonesia. Untuk mengakses lagu yang disediakan oleh iTunes pengguna diharuskan untuk membayar langganan pada platform tersebut, pembayaran yang dilakukan oleh pengguna iTunes tersebut kemudian diterima oleh iTunes dan dengan perhitungan tarif royalti yang telah ditentukan maka iTunes membayar sejumlah uang kepada LMK yang berbasis di Indonesia untuk disalurkan kembali kepada pencipta atau pemegang hak cipta. Jadi penerimaan royalti tidak hanya terdapat di satu Negara yang sama saja melainkan berasal dari Negara yang berbeda. 
LMK yang dimaksud sebagai penerima royalti dari iTunes adalah Wahana Musik Indonesia yang mana pada tahun 2017 telah menerima royalti atas pembayaran yang dilakukan oleh iTunes dan Sonylive, yang mana keduanya merupakan produk dari perusahaan besar yang bermarkas di luar negeri. Royalti yang dibayarkan oleh iTunes dan Sonylive senilai Rp. 1.200.000.000,- ( satu milyar dua ratus juta rupiah) yang mana pembayaran tersebut atas penggunaan lagu-lagu pada layanan digital pada priode 2013 -2015 yang mana lagu-lagu tersebut telah dikuasakan oleh Pencipta atau Pemegang Hak Cipta kepada Wahana Musik Indonesia.

Berdasarkan hasil wawancara yang dilakukan penulis terhadap pencipta lagu serta penyanyi yaitu Erdian Aji Prihartanto yang lebih dikenal dengan nama panggung Anji mengatakan bahwa sebagai pencipta lagu agar dapat menerima royalti serta mendapatkan perlindungan diwajibkan untuk mendaftarkan diri atau dengan kata lain harus menjadi anggota LMK terlebih dahulu, pengaturan menegenai kewajiban seorang Pencipta untu menjadi anggota dari sebuah LMK sendiri telah diatur dalam Undang-Undang Hak Cipta Pasal 87 Ayat 1. Tujuan dari menjadi anggota sebuah LMK adalah agar hak-hak yang dimiliki oleh Pencipta lagu tidak hilang atau tidak mudah dilanggar begitu saja. Berdasarkan pernyataan yang diberikan oleh Anji yang merupakan seorang pencipta lagu serta penyanyi dapat disimpulkan bahwa sebagai seorang Pencipta memiliki harusan untuk mendaftarkan diri kepada LMK supaya ciptaannya mendapatkan perlindungan, karena pada dasarnya sebuah karya cipta yang telah dihasilkan dalam bentuk yang dapat dilihat, didengar atau dinikmati orang lain secara otomatis mendapatkan perlindungan hukum hal ini telah diatur pada perjanjian internasional yang mana telah mendapatkan persetujan negara-negara anggota yang mana terdapat 3 (tiga) prinsip-prinsip dasar yang kemudian menjadi acuan dalam memberikan perlindungan hukum terhadap hak cipta hal ini dibuktikan dengan dimasukannya penerapan prinsip-prinsip dasar kedalam Pasal 1 UndangUndang tentang Hak Cipta.

Akan tetapi pada kenyataan dilapangan peraturan tersebut belum dijalankan dengan semestinya. Hal ini yang menyebabkan ketidak berjalannya antara peraturan yang ada dengan kondisi yang ada dilapangan sehingga pemerintah perlu melakukan tindakan yang diharapkan dapat menjalankan perlindungan hukum sesuai dengan Pasal 1 tersebut.

Anji memiliki kesadaran yang cukup tinggi terhadap perlindungan hak cipta tersebut terutama dalam bidang hak eksklusif yag mana menurut pandanganya banyak orang yang melakukan atau menggunakan lagu karya orang lain dengan tujuan komersil namun enggan untuk meminta izin ataupun memberikan sebagian hasil dari penggunaan lagu tersebut, sehingga anji turut serta untuk memberikan kesadaran terhadap masyarakat terkususnya kepada teman-teman musisi seperti dirinya untuk lebih sadar dengan hak cipta serta turut serta dalam menjalankan peraturan yang telah ada.

Upaya yang pemberian pengetahuan terhadap pentingnya menghargai hak cipta orang lain dilakukan dengan mengunggah postingan di instagram. Anji dalam caption instagramnya memberikan saran atau masukan bagi para musisi ataupun Pengguna (user) dengan tujuan komersial diharapkan dapat menghubungi Pencipta lagu terlebih dahulu karena pada dasarnya penggunaan ciptaan orang lain dengan tujuan komersial haruslah memiliki ijin dari Pencipta, dengan harapan Pengguna (user) dapat memberikan atau membagi sedikit hasil komersilnya tersebut dengan Pencipta sebagai suatu bentuk apresiasi terhadap Ciptaan yang telah dipergunakan. 
Selain dengan memberikan edukasi atau pemamparan meneganai pentingnya menghargai sebuah hak cipta anji juga sering menyuaran pendapatnya tersebut dalam segala sesi wawancara, kali ini ketika sedang diundang pada proadcast disalah satu kanal sebuah acara, ia memberikan gambaran bahawasanya sering kali yang mempergunakan lagu tersebut lebih sukses dalam artian memiliki ekonomi yang lebih banyak ketimbang Pencipta lagu itu sendiri. Anji juga memperumpamakan apabila hak eksklusif yang telah diatur dalam peraturan perundang-undangan terkait Hak Cipta dapat dikatakan Pencipta dapat hidup makmur tanpa harus mendapatkan job in air ataupun off air, gambaran ini menyatakan dengan dipenuhinya hak menggumumkan dan hak mekanikal sudah pasti pendapatan Pencipta atas dipergunakan lagu tersebut telah lebih dari cukup.

Tidak berjalannya Pasal 1 angka 1 dalam memberikan perlindunga hukum pada ciptaan lagu sehingga para pencipta diharuskan untuk mendaftarkan diri sebagai anggota dari LMK guna mendapatkan perlindungan atas ciptaan yang dihasilkan, mengapa penulis katakan diharuskan menjadi anggota hal ini karena apabila tidak menjadi anggota LMK maka hasil ciptaan lagu tersebut tidak dapat dilindungi serta tidak memiliki pembuktian bahwasanya memang benar lagu tersebut adalah ciptaan Pencipta. Dengan kata lain LMK merupakan sebuah tempat bernaung para Pencipta dalam melakukan pendistribusian ataupun penggunaan ciptaan yang kemudian dari pada itu Pencipta mendapatkan hasil dari pendistribusian atau penggunaan ciptaan berupa royalti. Namun apabila Undang-undang tentang Hak Cipta berjalan dengan baik, tanpa adanya LMK suatu ciptaan lagu memiliki perlindungan hukum sesuai dengan peraturan yang berlaku.

Pentingnya seorang Pencipta lagu menjadi anggota dari suatu LMK adalah untuk dapat memiliki haknya sepenuhnya serta memiliki bukti bahwa ciptaan yang dihasilkan memang benar milik Pencipta, karena dengan menjadi anggota suatu LMK dapat mendapatkan manfaat yang baik dalam pelaksanaan pendistribusian lagu serta dalam penerimaan royalti, serta apabila terjadi sengketa hukum terhadap ciptaan lagu yang menjadi pembuktian adalah LMK tersebut.

Dalam melakukan pembuktian terhadap ciptaan lagu akan sedikit sulit apabila Pencipta atau Pemilik Hak Cipta tidak menjadi anggota dari sebuah LMK, karena tidk memiliki sanksi serta dokumen yang kuat atas terciptanya sebuah karya lagu tersebut, karena dalam era digital seperti saat ini bukan hal yang mengherankan lagi apabila ada orang yang menyanyikan lagu orang lain dan kemudian mendapat keuntungan dari menyanyi tersebut. Memang pada haketatnya Pencipta adalah seorang yang menghasilkan karya orisinil dan dalam hal karya lagu adalah yang melakukan penerbitan untuk yang pertama kalinya, namun apabila ada orang lain yang kemudian mengaku bahwa ciptaan tersebut adalah lagunya dan mendaftarkannya maka Pencipta atau Pemilik Hak Cipta tidak memiliki bukti kuat atas lagu ciptaan tersebut, maka dari itu untuk melindungi hasil ciptaan maka Pencipta dan Pemegang Hak Cipta harus mendaftarkan diri atau menjadi anggota LMK terlebih dahulu.

Sebagai Pengguna (user), pemilik karaoke diwajibkan untuk membayar royalti terhadap lagu-lagu yang ditampilkan. Dengan adanya LMK yang menjadi naungan para pencipta serta penentuan tarif yang tidak sama sehingga pemerintah membentuk sebuah LMKN yang mana LMKN merupakan lembaga yang mengkoordinasi LMK yang ada di bawahnya. LMKN merupakan lembaga yang menentukan besaran tarif royalti yang harus dibayarkan oleh Pengguna (user) hal ini diharapkan tidak ada 
tumpang tindih atas besaran tarif royalti yang diberikan LMK seperti sebelum adanya LMKN tersebut.

Besaran tarif yang harus dibayarkan oleh usaha karaoke telah dikeluarkan oleh LMKN yang mana terdapat perbedaan antara tarif karaoke eksklusif berbeda dengan tarif karaoke keluarga sehingga terjadi perselisihan antara LMKN dengan Asosiasi Pengusaha Hiburan Jakarta (ASPHIJA), namun dengan adanya koordinasi yang baik yang melibatkan Kementerian Hukum dan Ham terjadi kesepakatakan dengan ditanda tanganinya MoU. Sehingga dapat dipastikan pembayaran royalti akan dilakukan sesuai dengan MoU tersebut.

Dalam penggunaan sebuah lagu dengan tujuan komersial tidak hanya dilakukan oleh tempat-tempat karaoke, restaurant, layanan musik online ataupun hotel melainkan pada saat ada dilaksanakannya konser. Hal ini juga untuk yang pertama kalinya terjadi setelah ada pengesahan Undang-Undang Hak Cipta. Pembayarkan royalti terhadap berlangsungnya atas penyelenggaraan konser, hal ini dilakukan oleh Universitas di Indonesia yang kala itu sedang mengadakan acara tahunan yaitu Festival Jazz Goes To Campus atau yang lebih dikenal denga JGTC yang dilaksanakan oleh Fakultas Ekonomi Universitas Indonesia, pada acara JGTC yang ke-39 (tiga puluh sembilan).

Untuk pertama kalinya penyelenggara melakukan penghargaan kepada komposer atau Pencipta lagu dengan melakukan kerja sama dengan Wahana Musik Indonesia (WAMI) guna untuk melakukan pembayaran royalti Komposer atau Pencipta lagu, dalam pengambilan royalti WAMI mendapatkan 20\% (dua puluh persen) dari harga tiket dengan skema pembayaran terhadap Komposer atau Pencipta lagu dilakukan dengan beberapa tahapan yaitu pembayaran yang dilaksanakan sebelum dan sesudah acara berlangsung. Pembayaran royalti yang dilakukan pada JGTC adalah moment yang untuk pertama kalinya Komposer atau Pencipta lagu menerima royalti atas berlangsungnya suatu pertunjukan, hal ini dilakukan oleh Penyelenggara dengan harapan dapat turut serta melaksanakan peraturan perundang-undangan yang telah ada serta memberikan apresiasi terhadap para Pencipta.

Pada dasarnya segala bentuk Hak Cipta mendapatkan sebuah perlindungan hukum yang telah dituangkan dalam undang-undang hak cipta yang berlaku, hanya saja apa yang terjadi pada kehidupan dilapangan tidak sesuai dengan peraturan yang ada. Dalam memberikan hukuman baik itu pidana penjara maupun denda telah diatur juga dalam Pasal 113. Dengan adanya peraturan perunang-undangan merupakan peran pemerintah dalam melindungi para Pencipta atas karya yang telah diciptakan.

Walau telah dibentuk peraturan yang telah megatur mengenai hak cipta ataupun telah diatur mengenai besaran hukuman penjara dan denda tidak serta merta membuat masyarakat sadar bahwa ciptaan merupakan suatu hak cipta yang melekat pada Pencipta atau Pemegang Hak Cipta yang mempunyai kewenangan terhadap hak eksklusif, karena hal ini juga tidak jauh dari pemikiran masyarakat yang menganggap bahwasanya lagu merupakan milik setiap orang, padahal jika diteluri lebih dalam sebuah karya cipta itu tidaklah mudah untuk di hasilkan, yang mana dalam proses pembuatan ciptaan memerlukan pemikiran, ketekunan dan kesabaran untuk menghasilkan ciptaan lagu tersebut.

Pemberlakuan aturan tersebut tidak serta merta menghilangkan sengketa dalam penggunaan lagu secara komersil hal ini dilihat dengan masih maraknya kasus atas pelanggaran hak cipta yang dilaksanakan oleh Pengguna (user) terhadap ciptaan dengan tujuan komersil. Hal ini ditandai dengan masih ada putusan hukum yang 
menanggani permasalahan sengketa hak cipta seperti pada kasus putusan pengadilan dengan nomor 670/Pid.Sus/2015/PN Sgl yang mana Pengguna (user) tidak memiliki lisensi serta tidak membayar royalti atas penggunaan lagu-lagu yang ditampilkan dalam usaha karaokenya sehingga atas dasar pelanggaran tersebut Pengguna (user) dikenakan kurungan penjara selama 1 (satu) bulan dan dikenakan denda Rp 2.000.000,- (dua juta rupiah).

Pelanggaran terhadap hak cipta tidak hanya terjadi antara pemilik usaha saja melainkan juga sesama musisi atau penyanyi yang mana menyanyikan lagu orang lain lalu menjual hasil nyanyian tersebut ke kalayak umum Tanya meminta izin atau memiliki lisensi dari Pencipta atau Pemegang Hak Cipta. Kasus ini terjadi di Jawa Timur dengan Putusan Pengadilan nomor 10/Pid.B/2014/PN Njk, dalam amar putusan penyanyi dikenakan hukuman 4 (empat) bulan penjara dengan denda sebesar Rp 1.000.000,- (satu juta rupiah).

Dalam pelanggaran yang dilakukan oleh penyanyi merupakan sebuah pelanggaran yang melanggar hak moral dan hak ekonomi, hal ini dikarenakan dengan adanya penjualan CD atas karya cipta agu Pencipta tanpa mencantumkan nama Pencipta lagu, disisi lain sebuah ciptaan merupakan suatu perwujudan dari akal fikir yang dilakukan oleh Pencipta sehingga sangat diperlukan dalam memberikan apresiasi baik dalam bentuk peberian uang atau royalti maupun dalam bentuk hal yang di kesepakati kedua belah pihak.

Pemberlakuan pidana serta denda terhadap pelanggaran Hak Cipta harusnya membuat semua orang sadar bahwa hak cipta memiliki nilai ekonomis dan memiliki pemilik atas setiap ciptaan lagu-lagu tersebut, sehingga masyarakat memiliki kesadaran untuk menjaga serta memberikan sebuah penghargaan terhadap hasil karya orang lain dengan tidak mempergunakan hasil ciptaan lagu tanpa memiliki lisensi apalagi ciptaan lagu yang diperuntukan untuk diambil hak ekonominya.

Pembelakuan ketentuan pidana serta denda merupakan bukti nyata keseriusan pemerintah dalam melindungi hak-hak para Pencipta karya lagu sehingga dengan adanya perlindungan ini diharapkan bagi semua orang untuk tidak takut dalam mengembangkan kreativitas yang dimiliki sehingga dapat memunculkan karyakarya yang baru serta relevan sesuai dengan perkembangan jaman.

\section{Penyelesaian Sengketa atas Penggunaan Karya Lagu Tanpa Membayar Royalti}

\section{i. Penyelesaian Sengketa Melalui Litigasi}

Dalam upaya menyelesaikan sengketa Pencipta atau Pemegang Hak Cipta dengan melalui litigasi dapat dilakukan dengan mengajukan gugatan ganti kerugian ke Pengadilan Niaga atas pelanggaran terhadap hak cipta yang dimiliki yang mana sesuai dengan ketentuan pasal 95 Ayat 2. Dengan diajukannya gugatan terhadap pelanggar hak cipta maka Pencipta dapat memperoleh besaran ganti rugi sesuai denegan apa yang ia rasakan, kerugian yang dimaksud adalah kerugian materil dan kerugian immaterial.

Penggunaan karya cipta lagu tanpa seizing dari Pencipta merupakan bentuk pelanggaran, terlebih lagi apabila pelanggaran tersebut mendapatkan keuntungan sedangkan Pencipta tidak mendapatkan keuntungan padahal Pencipta telah bersusah paya dalam menwujdukan karya cipta lagu tersebut, maka untuk mendapatkan manfaat dan mengambil kembali apa yang telah Pencipta wujudkan, dapat mengambil langkah ke Pengadilan Niaga. Dalam melakukan tata cara gugatan 
dapat dilihat dalam Pasal 100 Undang-Undang Hak Cipta yang mengantur proses pengajuan hingga ahkir.

Namun apabila Pencipta atau Pemegang Hak Cipta juga dapat melakukan tuntutan pidana terhadap karya lagu yang dilanggar sehingga pengguna (user) mendapatkan efek jera. Pelanggaran hak cipta di Indonesia sering terjadi salah satunya adalah terhadap putusan-putusan yang bersangkutan dengan pelanggaran hak cipta seperti berikut.

Seperti pada kasus putusan pengadilan dengan nomor 670/Pid.Sus/2015/PN Sgl yang mana Pengguna (user) merupakan pemilik dari sebuah usaha karaoke yang mempergunakan hak menggumumkan atas lagu-lagu tanpa memiliki perizinan atau perjanjian lisensi yang berasal dari Pencipta atau Pemegang Hak Cipta, akibatnya tindakan Pengguna (user) termasuk kedalam kategori tindakan pelanggaran Hak Cipta terhadap Undang-Undang Nomor 28 Tahun 2014 tentang Hak Cipta. Terlebih dalam usahanya tersebut Pengguna (user) tidak pernah membayarkan royalti atas penyiaran lagu-lagu di tempat usahanya, padahal dengan jam operasional karaoke serta ruangan karaoke yang disediakan Pengguna (user) mampu menerima pendapatan Rp. 15.000.000,- (lima belas juta rupiah) setiap bulannya, hal ini berbanding terbalik terhadap Pencipta atau Pemegang Hak Cipta yang tidak mendapatkan sepeserpun atas karya Cipta yang dimilikinya. Hal demikianlah yang membuat Pencipta atau Pemilik Hak Cipta memiliki hidup yang jauh dari kata mewah padahal karya lagu yang dihasilkan terbilang sukses di pasaran.

Pada dasarnya pelanggaran hak cipta lagu tidak hanya terjadi pada tempat hiburan seperti karaoke, restoran dan café saja melainkan juga bisa berasal dari sesame musisi atau penyanyi yang mempergunakan ciptaan lagu tanpa meminta ijin dari Pencipta dan tentu saja penggunaan Ciptaan lagu tersebut diperuntukan untuk komersil. Hal ini pernah terjadi pada tahun 2014 silam yaitu berdasarkan putusan pengadilan nomor 10/Pid.B/2014/PM Njk, sengketa ini dilatar belakangi oleh penggunaan lagu Oplosan yang merupakan Ciptaan Nur Salam pada tahun 2008 yang mana telah diumumkan untuk pertama kalinya dengan menggunakan media VCD (cakram optik) yang saat itu di nyanyikan oleh Trio Gomik Feat Nur Bayan dengan aransemen jaipong pada bulan Juni tahun 2008. Pada acara penyambutan tahun baru 2013 di Daerah Sumber Boto Kabupaten Jombang, Eni Setyaningsih als Eni Sagita yang beralamat di Dusun Tanjung Desa Pace kulon Kecamatan Pace Kabupaten Nganjuk dengan iringian Om Sagita tanpa seijin pencipta lagu telah menyanyikan lagu dengan judul Oplosan dan nyanyian tersebut kemudian di dokumentasikan dengan cara direkam oleh D'va Shoting dan kemudian oleh Eni Sagita dicetak berupa kepingan VCD.

Pada tanggal 15 Januari tahun 2013, Ketua Operasional APPRI telah melaksanakan pengecekan pada beberapa tempat penjualan VCD di daerah Jawa Timur dari pengecekan yang dilakukan oleh ketua operasional APPRI menemukan bahwa telah beredar sebuah VCD yang memuat lagu dengan judul Oplosan dengan nama penyanyi Eni Sagita. Mengetahui hal tersebut ketua operasional APPRI menanyakan kepada Pencipta lagu Oplosan mengenai pemberian lisensi yang diberikan kepada Eni Sagita, namun Pencipta lagu Oplosan tidak pernah memberikan lisensinya kepada penyanyi tersebut maupun kepada pihak-pihak yang berada pada VCD tersebut. Tidakan yang dilakukan oleh Eni Eni Sagita sebagai terdakwa dalam menyanyikan lagu Oplosan tanpa mendapatkan izin dari Pencipta merupakan tindakan yang melanggar Undang-Undang Nomor 19 tahun 2002 
Tentang Hak Cipta. Pengadilan Negeri Nganjuk menyatakan bahwa Eni Sagita telah terbukti secara sah dan meyakinkan bersalah melakukan tindak pidana serta menjatuhkan pidana terhadap terdakwa dengan pidana penjara selama 4 (empat) bulan dengan masa penahanan yang telah dijalani terdakwa dikurangkan seluruhnya dari pidana dikurangi masa tahanan selama pesehingga pidana tersebut tidak usah dijalani. Menjatuhkan pidana denda kepada terdakwa untuk membayar denda sebesar Rp. 1.000.000,- (satu juta rupiah) dengan ketentuan apabila denda tersebut tidak dibayar maka diganti dengan pidana kurungan selama 1 (satu) bulan. Serta menetapkan agar barang bukti berupa VCD yang memuat lagu Oplosan yang diyanyikan oleh terdakwa dirampas dan dimusnahkan. Membebankan terdakwa untuk membayar biaya perkara sebesar Rp 5.000,- (lima ribu rupiah).

Dasar dari pemberian perlindungan hukum dikarenakan maraknya kejadian pelanggaran hak cipta ataupun pengeksploitasian terhadap ciptaan yang menyebabkan Pencipta atau pemegang Hak Cipta dirugikan, yang mana pelanggaran yang dilakukan sering kali berkaitan dengan penggunaan hak eksklusif yang dipunyai oleh Pencipta atau pemegang Hak Cipta yang digunakan oleh Pengguna (user) tidak memiliki tanggung jawab dikarenakan penggunaan Ciptaan tersebut didasari dengan tidak adanya perjanjian lisensi atau izin dari Pencipta atau Pemegang Hak Cipta.

Perlidungan hukum terhadap Hak Cipta diharapkan dapat menjamin hak-hak yang dimiliki Pencipta atau Pemegang Hak Cipta serta menjadi landasan agar dapat mengurangi kerugian apabila terjadi pelanggaran Hak Cipta dalam segi materil dan immateril. Pemberian hukuman pidana penjara serta pemberlakukan pembayaran denda merupakan tujuan dari beberapa fungsi dalam memberikan efek jera kepada pelaku pelanggaran hak cipta, sehingga dengan adanya pemberlakukan tersebut dapat meminimalisir tindakan pelanggaran yang ada.

Regulasi yang ada dalam pengaturan terhadap perlindungan hukum sebagai bentuk pencegahan dalam terjadinya suatu tindak pelanggaran atau yang biasa disebut sebagai penggunaan hukum preventif yang mana dengan adanya UndangUndang Nomor 28 tahun 2014 Tentang Hak Cipta sebagai peraturan yang mengatur mengenai Hak Cipta terhadap ciptaan yang dilindungi, namun masih banyak Pengguna (user) yang tidak mempedulikan peraturan tersebut. Sehingga perlu adanya pengawasan terhadap Pengguna (user) dalam mempergunakan karya lagu dalam kegiatan usahanya baik dalam karaoke ataupun kegiatan yang berkenaan dengan penggunaan hak menggumumkan, sehingga dengan demikian tindakan pelanggaran terhadap hak cipta dapat terminimalisir.

Dengan demikian perlindungan hukum yang dilakukan secara preventif yang telah ada masih belum mampu untuk memberantas pelanggaran hak cipta sehingga diperlukan sebuah tindakan yang dapat memberikan hukuman serta memberi efek jera terhadap pelanggaran hak cipta yang mana bisa dilakukan dengan menggunakan metode perlindungan hukum secara represif yang pemberian hukuman sesuai dengan peraturan undang-undnag yang berlaku.

\section{ii. Penyelesaian Sengketa Melalui Non Litigasi}

Seperti yang telah diketahui dalam upaya menyelesaikan permasalahan hukum atau sengketa tidak selalu dilakukan di pengadilan (litigasi) namun terdapat upayaupaya lain yang juga bertujuan menyelesaian sengketa tanpa menggunakan jalur pengadilan yaitu non litigasi. Pada dasarnya dalam upaya menyelesaian sebuah sengketa dapat dilakukan secara efektif melalui beberapa proses yaitu melalui 
proses alternatif penyelesaian sengketa, arbitrase dan pengadilan hal ini telah tertuang jelas pada Pasal 95 Ayat 1 Undang-Undang Hak Cipta.

Bentuk dari sengketa tersebut terkait dengan Hak Cipta yang berupa perbuatan melawan hukum, perjanjian lisensi, sengketa menegnai tarif dalam penarikan imbalan atau royalti, dalam upaya menyelesaikana sengketa menggunakan alternative penyelesaian sengketa adalah sebuah proses yang dilakukan kedua belah pihak yang bersengketa dengan melalui mediasi, negosiasi dan konsiliasi. Pada dasarnya sebelum dilakukan tuntutan pidana, para pihak diharuskan melakukan melakukan penyelesaian sengketa dengan melalui mediasi terlebih dahulu.

Alternatif penyelesaian sengketa merupakan lembaga yang menangani penyelesaian sengketa yang terjadi akibat dari perbedaan pendapat melalui prosedur yang telah di kesepakati oleh kedua belah pihak. Untuk lebih lanjut dalam menenyelesaikan sengketa melalui jalur arbitrase di Indonesia telah diatur dalam Undang-Undang Nomor 30 Tahun 1999 Tentang Arbitrase dan Penyelesaian Sengketa.

Keuntungan menyelesaian sengketa menggunakan jalur non litigasi jika di bandingkan dengan penyelesaian sengketa melalui jalur litigasi adalah sidang tertutup untuk umum, prosesnya cepat yaitu maksimal enam bulan, putusannya final dan tidak dapat dibanding atau kasasi, arbiternya dipilih oleh para pihak, ahli dalam bidang yang disengketakan, dan memiliki integritas atau moral yang tinggi, meskipun biaya formalnya lebih mahal daripada biaya pengadilan, tetapi tidak ada biaya-biaya lain dan khusus di Indonesia, para pihak dapat mempresentasikan kasusnya dihadapan Majelis Arbitrase dan Majelis Arbitrase dapat langsung meminta klarifikasi oleh para pihak. Selain itu dalam penggunaan arbitrase identitas kedua belah pihak dapat di sembunyikan dengan artian tidak ada yang mengetahui persoalan tersebut kecuali kedua belah pihak yang sedang bersengketa.

Pada dasarnya dalam penggunaan hak ekonomi yang dipergunakan oleh Pengguna (user), Pencipta atau Pemegang Hak Cipta berhak untuk memperoleh ganti rugi sesuai dengan ketantuan Pasal 96 Undang-Undang Hak Cipta.

Lingkup penggunaan terhadap karya cipta tidak hanya dipergunakan oleh Pengguna (user) yang berada pada negara yang sama dengan Pencipta atau Pemegang Hak Cipta melaikan dapat juga dipergunakan diberbagai negara yang berbeda dengan Pencipta karya hal ini dikarenakan perkembangan zaman yang kian modern dan telah pada era revolusi industri 4.0 perkembangan ini dapat dilihat dengan adanya pembayaran royalti yang dilakukan oleh layanan musik iTunes yang merupakan produk dari Apple Inc. yang berbasis di Amerika Serikat dan Sonylive merupakan layanan mengunduh musik yang di kelola oleh Sony Music Entertaiment yang memiliki kerjasama dengan Sony Ericsson yang telah menjadi bukti nyata bahwa penggunaan karya cipta lagu juga dipergunakan dibelahan negara lain. Sehingga sangat mungkin apabila pelanggaran terhadap gak cipta juga dapat terjadi pada negara yang berbeda dengan Pencipta atau Pemegang Hak Cipta.

Pelanggaran terhadap hak cipta yang terjadi pada negara yang berbeda telah masuk pada ranah internasional karena hukum yang dipergunakan bukanlah hukum dari masing-masing negara melainkan dalam penyelesaian sengketa internasional umumnya mempergunakan hukum internasional yang telah disetujui para pihak yang bersengketa. Namun dalam sengketa hak cipta upaya penyelesian sengketa dapat dilakukan dengan mempergunakan organisasi yang sama yang mana masingmasing negara merupakan anggota dari organisasi tersebut, seperti halnya 
Indonesia merupakan anggota dari World Intellctual Property Organization atau lebih di kenal dengan WIPO sehingga apabila Pencipta atau Pemegang Hak Cipta lagu yang berasal dari Indonesia dan ingin menyelesaian sengketa yang berkenaan dengan pelanggaran hak cipta maka dapat mengajukan penyelesaian sengketa melalui Pusat Arbitrase dan Mediasi WIPO.

Pusat Arbitrase dan Mediasi WIPO adalah sebuah lembaga non litigasi yang menyediakan penyelesaian sengketa yang bersifat netral, internasional dan lembaga yang tidak mencari keuntungan (non-profit) yang manawarkan pilihan dalam memberikan solusi dalam alternative penyelesaian sengketa (alternative dispute resolution) yang mana dalam penyelesaian sengketa dengan jalur ini lebih hemat waktu. Dengan mempergunakan Pusat Arbitrase dan Mediasi WIPO dapat melakukan arbitrase yang dilakukan dengan cepat, dan menggunakan pendapat ahli sehingga memungkinkan pihak-pihak yang bersengekta secara efisien dapat menyelesaiakan permasalahan terkait hak cipta dalam tingkatan nasional atau internasional yang dilakukan diluar penggadilan.

Pusat arbitrase dan mediasi wipo pada tanggal 19 juli 2019 menangani sebuah sengketa antara penerbit musik besar dan independen BMG, Peermusic, Penerbitan Musik Sony / ATV / EMI, Penerbitan Universal Music dan Warner / Chappell Music serta AEDEM dan lebih dari 200 penerbit musik Spanyol ukuran kecil dan menengah, dengan lembaga SGAE hak kolektif Spanyol. Dalam sengketa ini arbitrase yang menangani sengketa ini lebih memfokuskan terhadap dua hal utama yaitu yang peratama terhadap penerimaan royalti yang tidak adil dari Pengguna (user) lagu kepada lembaga SGAE yang kemudian di distribusikan kembali kepada Pencipta atau Pemegang Hak Cipta. Permasalahan kedua yaitu terhadap pendistribusian royalti yang tidak tepat sasaran karena di distribusikan juga kepada Pencipta atau Pemegang Hak Cipta terhadap lagu yang tidak disiarkan.

Setelah mempertimbangkan bukti yang telah diterima oleh arbiter, maka tiga arbiter WIPO memutuskan SGAE harus memiliki peraturan yang baru atas pendistribusian royalti yang mana pendistribusian atau pembagian royalti harus bersifat adil agar tidak merugikan Pencipta atau Pemegang Hak Cipta lain. Pendistribusian royalti terhadap musik yang tidak terdengar harus dihentikan, sebagaimana yang telah di identifikasi oleh penggunaan teknologi perusahaan BMAT Spanyol atau perusahaan yang menggunakan teknologi serupa.

Berdasarkan penyelesaian sengketa antara penerbit musik dengan lembaga SGAE hak kolektif Spanyol yang mana mempermasalahkan pembagian atau pendistribusian royalti terahadap Pencipta atau pemegang Hak Cipta dapat diselesaikan dengan mempergunakan mediasi ataupun arbitrase yang telah disediakan oleh WIPO, dalam hal ini bukan hal yang tidak mungkin bagi negaranegara lain untuk mempergunakan pusat Arbitrase dan Mediasi WIPO dalam menyelesaikan sengketa internasional ataupun sengketa yang terjadi antara para pihak yang saling sepakat untuk mempergunakan organisasi arbitrase, karena pada dasarnya upaya ini dilakukan untuk mencari solusi atau putusan yang terbaik bagi kedua belah pihak yang bersengketa. 


\section{E. Kesimpulan}

Kesimpulan yang dapat diambil berdasarkan hasil analisis terhadap Perlindungan Hukum Terhadap Karya Cipta Lagu Dalam Pembayaran Royalti yaitu sebagai berikut:

1. Perlindungan hukum hak cipta atas karya lagu tidak terlaksana dengan baik hal ini dikarenakan peraturan perundang-undangan tidak mampu untuk memberikan perlindungan sehingga cara preventif sebagai bentuk pencegahan tidak berjalan sesuai dengan peraturan perundang-undangan, namun perlindungan hukum dengan cara represif yaitu sebuah kesempatan yang diberikan oleh negara untuk memperoleh haknya melalui proses hukum sesuai dengan peraturan perundangundangan nomor 28 tahun 2014 tentang hak cipta.

2. Penyelesaian sengketa dapat dilakukan melalui 2 (dua) metode yaitu penyelesaian melalui litigasi yaitu dengan mengajukan gugatan ganti rugi terhadap hak cipta yang telah dilanggar ke Pengadilan Niaga dan melalui non litigasi yang mana merupakan penyelesaian sengketa yang berada diluar Pengadilan, dan menujuk Arbitrase yang dikesepakati oleh kedua belah pihak seperti Pusat Arbitrase dan Mediasi WIPO. 


\section{DAFTAR PUSTAKA}

\section{Buku}

Agus Trianto, Pasti Bisa Pembahasan Tuntas Kompetensi Bahasa Indonesia Untuk SMP dan MTs kelas VIII, Jakarta: Esis, 2007.

Andrian Sutedi, Hak Atas Kekayaan Intelektual, Jakarta: Sinar Grafika, 2013.

Bambang Sunggono, Metode Penelitian Hukum (Suatu Pengantar), Jakarta: PT Raja Grafindo Persada, 2001.

Beall, Eric, The Billboard Guide to Writing and Producing Songs That Sell, New York: Watson- Guptill Publications, 2009.

Bronto Asmoro, Buku Saku Super Pintar IPS “Ilmu Pengetahuan Sosial”, Jakarta: Grasindo, 2010.

Eddy Damian, Hukum Hak Cipta, Bandung: ALUMNI, 2002.

Elsi Kartika Sari dan Advendi Simangunsong, Hukum dalam Ekonomi, Jakarta: Grasindo, 2004.

Etty Susilowati, Hak Kekayaan Intelektual dan Lisensi Pada HKI, Semarang: Penerbit Undip Press, 2013.

Gatot Supramono, Hak Cipta dan Aspek-Aspek Hukumnya, Jakarta: PT. Rineka Cipta, 2010.

Hendra Tanu Admadja, Hak Cipta Musik atau Lagu, Cet.1, Program Pasca Sarjana, Fakultas Hukum, Universitas Indonesia, Jakarta, 2003.

Henry Campbell Black, Black's Law Dictionary, West Publishing Co: Revised Fourth Edition, 1968.

Inglis, Sam, Get Started in Songwriting: The Essential Guide To Writing, Performing, Recording, and Selling your music and lyrics, London: Hodder \& Stoughton, 2010.

Kholis Roisah, Konsep Hukum Hak Kekayaan Intelektual (HKI): Sejarah, Pengertian, dan Filosofi Pengakuan HKI dari Masa ke Masa, Malang: Setara Press, 2015.

Philipus M. Hadjon, Perlindungan Hukum Bagi Rakyat di Indonesia, Surabaya: Bina Ilmu, 1987.

Roessner, Jeffrey, Creative Guitar: Writing and Playing Rock Songs With Originality, Fenton: by mel bay publications, 2009.

Sendjaja Widjaja, Dodi Mawardi, HITS Maker- Panduan Menjadi Produser Rekaman Jempolan, Jakarta: PT. Elex Media Komputindo, 2009.

Sentosa Sembiring, Kekayaan intelektual Dalam berbagai Peraturan PerundangUndanga, Bandung: CV. Yrama Widya, 2002

Sila Widhyatama, Sejarah Musik dan Apresiasi Seni, Jakarta: PT Balai Pustaka (Persero), 2012. 
Syahruddin Nawi, Penelitian Hukum Normatif Versus Penelitian Hukum Empiris, Cet. 6, Makassar: PT Umitoha Ukhuwah Geafika, 2018.

Tim Visi Yustisia, Panduan Resmi Hak Cipta: Mulai Mendaftar, Melindungi, dan Menyelesaikan Sengketa, Jakarta: Visimedia, 2015.

Zainuddin Ali, Metode Penelitian Hukum, Cet. 7, Jakarta: Sinar Grafika.

\section{Artikel Jurnal}

Ghaesany Fadhila, dan U. Sudjana, Perlindungan Karya Cipta Lagu Dan/Atau Musik Yang Dinyanyikan Ulang (Cover Song) di Jejaring Media Sosial Dikaitkan Dengan Hak Ekonomi Berdasarkan Undang-Undang Nomor 28 Tahun 2014 Tentang Hak Cipta, Bandung: Acta Diural Universitas Padjajaran, Jurnal Juni 2018, Vol. 1, Nomor 2, hlm 222-235.

Emma Valentina Teresha Senwe, Efektifitas Pengaturan Hukum Hak Cipta Dalam Melindungi Karya Seni Tradisional Daerah, Jurnal LPPM Bidang Ekososbudkum Volume 2 Nomor 2 Tahun 2015 Edisi Oktober, 2015.

Habi Kusno, Perlindungan Hukum Hak Cipta Terhadap Pencipta Lagu yang Diunduh Melalui Internet, Fiat Justisia, Volume 10 Issue 3, 2016.

Hendra Tanu Admadja, Hak Cipta Musik atau Lagu, Cet.1, Program Pasca Sarjana, Fakultas Hukum, Jakarta: Universitas Indonesia, 2003.

Imam Ghozali, Pembelajaran Musik Berbasis Siswa dengan Pendekatan Vocal Genius, Jurnal Visi Ilmu Pendidikan Vol. 7 No. 1, 2012

Katerina R, Etty S, dan Rinitami N, Pelaksanaan Perjanjian Lisensi Hak Cipta Atas Lagu Antara Pencipta Lagu Dengan Produser Rekaman Suara, Diponegoro Law Jurnal, Vol. 5 No. 3, 2016.

Maria Alfons, Implementasi Hak Kekayaan Intelektual Dalam Perspektif Negara Hukum, Jurnal Legislasi Indonesia Vol. 14 No. 03 - September 2017

Rezky Lendi Maramis, Perlindungan hukum Hak Cipta atas karya musik dan lagu dalam hubungan pembayaran royalti, Lex Privatum, Vol.II/No. 2/April/2014, hlm 116-125

\section{Internet}

Beritaagar.id dilihat pada 12 November 2019 dari https://beritagar.id/artikel/senihiburan/jgtc-2016-festival-musik-pertama-yang-membayar-royaltikomposer

Crefovi, Alternative Dispute Resolution in the entertainment and creative industries. Dilihat pada 23 Januari 2020 dari https://crefovi.com/articles/alternative-dispute-resolution-entertainmentcreative-industries/ 
Suryamerdeka.com dilihat pada 13 November 2019 dari https://www.suaramerdeka.com/entertainment/baca/287/pengusahakaraoke-eksekutif-jakarta-bayar-royalti-via-lmkn

Wahana Musik Indonesia, Digital Royalty Distributor, 18 May 2017. Diambil pada13Desember2019dari:https://www.wami.id/en/2017/05/18/distribusiroyalti-digital/

\section{Perundang-Undangan}

Undang-Undang Dasar Negara Republik Indonesia Tahun 1945

Undang-Undang Nomor 28 Tahun 2014 Tentang Hak Cipta

Peraturan Menteri Hukum dan Hak Asasi Manusia Nomor 42 Tahun 2016 